\title{
A evidência científica vai de encontro ou ao encontro da mudança de paradigma?
}

Mudança, em certo sentido, está na essência da ciência. Cada vez que utilizamos o armamentário estatístico para testar uma hipótese nula, tipicamente, torcemos para encontrar diferenças significativas. E há razão para isso. Por exemplo, se testarmos a hipótese nula de nunca ter havido vida em Marte e rejeitarmos essa hipótese, avançamos no conhecimento e assumimos a hipótese alternativa: houve vida no planeta vermelho. Assim, de rejeição em rejeição de hipóteses, avança a ciência*. Alguns avanços podem causar uma ruptura na linha de pensamento e proporcionar uma visão completamente nova sobre um assunto. Esse tipo de mudança tem uma denominação própria, é chamado mudança de paradigma.

Alguns termos são recorrentes no repertório científico, pois tangenciam tópicos de grande importância. Paradigma é uma dessas palavras e ela tem uma singularidade que vai além de sua importância. A palavra em si tem paternidade e data de nascimento. Foi cunhada por Thomas Kuhn em seu livro, de 1962, A Estrutura das Revoluções Científicas ${ }^{1}$.

A teoria de Kuhn sobre os mecanismos da ciência foi, por si própria, uma mudança de paradigma. Ele utilizou o termo paradigma com dois significados diferentes. De um lado, ele indica toda a constelação de crenças, valores, técnicas, etc, partilhados pelos membros de uma comunidade determinada. De outro, denota um tipo de elemento dessa constelação: as soluções concretas de quebra-cabeças, que são usadas como modelos pela ciência após a mudança ocorrer ${ }^{1}$.

O entendimento do statu quo do conhecimento quebrado na mudança de paradigma tem imbricada e complexa relação com outro conceito: a evidência científica. É interessante que muitos, equivocadamente, consideram as quebras de paradigma antagônicas à evidência científica. $\mathrm{O}$ antagonismo alegado consiste em ser a prática clínica baseada em evidências tolhedora dos avanços nas áreas. Entretanto, essas entidades devem ser compreendidas como espelho retrovisor e parabrisas; não se avança com segurança sem o auxílio dos dois.

Acompanhei, na última Conferência Britânica de Ortodontia, o lançamento de uma importante demonstração da inter-relação profícua entre os dois conceitos dentro da Ortodontia. Foi lançado, pela Sociedade Britânica de Ortodontia, o Guia para Radiografias Ortodônticas ${ }^{2}$. Nossos colegas responderam, baseados em evidência, a perguntas como: "precisamos de telerradiografias em todos os pacientes adultos que nos procuram para tratamento ortodôntico?" ou "precisamos do uso rotineiro de radiografias ou tomografias em pacientes com distúrbios temporomandibulares?".

A resposta para as duas perguntas é não, não precisamos. E, nesse caso, a evidência sugere uma quebra de paradigma quanto ao uso de radiografias em Ortodontia. Certamente, atitudes similares permitirão que reorientemos nossos padrões e isso afetará, com o adequado tempo e maturação dessas informações, os paradigmas da excelência clínica defendidos em órgãos como o Board Brasileiro de Ortodontia.

Já que estamos falando de mudanças, passa a vigorar a partir desse número da Revista Dental Press de Ortodontia e Ortopedia Facial o novo Acordo Ortográfico da Língua Portuguesa. Assim, os autores deverão enviar os trabalhos revisados, quanto ao vernáculo, em sintonia com o acordo ortográfico. Paralelamente, iremos editar os artigos, o tanto quanto for possível, de acordo com as novas regras.

Reafirmo, a mudança está na essência da ciência. Clínicos e cientistas devem permanecer atentos aos novos ventos que movimentam o conhecimento em nossa área.

Boa leitura,

Jorge Faber

Editor-chefe (faber@dentalpress.com.br)

* As hipóteses não rejeitadas também podem ser importantes avanços, ainda que sejam mal tratadas pelas revistas científicas. Tanto elas são importantes que há revistas dedicadas inteiramente a resultados negativos, tal como o Journal of Negative Results. Muitas vezes, elas podem sinalizar o simples e relevante fato de que não devemos explorar um certo assunto de uma certa maneira, e economizar, dessa forma, tempo e dinheiro de institutos de pesquisa para reprodução daquela metodologia.

\section{REFERÊNCIAS}

1. KUHN, T. A estrutura das revoluções científicas. 7. ed. São Paulo: Perspectiva. 2003. p. 218.

2. ISAACSON, K. G. et al. Orthodontic radiographs guidelines. 3rd. ed. London: British Orthodontic Society, 2008. 